\title{
Corpus, language, and linguistic practices
}

Lähivõrdlusi. Lähivertailuja ( $L V$ ) 'Close Comparisons' now appears already for the 24th time in its history, and this is the sixth issue published in the current format: $L V$ appears both online and on paper, as a publication series of the Estonian Association for Applied Linguistics. We are proud of this international series, which has in the last few years continuously grown in size, and we are happy to receive more and more article submissions on diverse issues of learning and understanding Estonian, Finnish and other Finno-Ugric languages. It seems that our series has established its position and found its way to readers interested in applied-linguistic research into Finno-Ugric languages. Of course, we cordially welcome all new readers and authors.

As in the preceding issues of $L V$, many articles in this 24th volume are based on talks given at a thematically closely related event: the workshop which was organised by the research network VIRSU (Finno-Ugric Target Languages) within the 2013 conference of AFinLA (the Finnish Association for Applied Linguistics) in Turku. However, there are also articles from other institutional contexts and research projects.

In addition to the VIRSU connections and the Finnic thematics, this volume also continues the tradition of presenting corpus-based and corpus-driven research of learner language. Pille Eslon investigates the functions of adverb constructions in Estonian literature and in learner language, on the basis of the Estonian Literary Language Corpus of the University of Tartu and the Estonian Interlanguage Corpus. In Estonianlanguage literature, adverb constructions are an important means of creating cohesion and smooth transitions in text, while in learner language their use is marginal and stereotypical. Although both language varieties 
employ the same constructions, their lexical and morphosyntactic variation is much more restricted in learner language.

Outi Toropainen, Nina Reiman, and Marja Seilonen have used the Cefling Corpus of the University of Jyväskylä. Toropainen investigates how students in their texts repeat those words (or word stems in related derivatives) which already appeared in the formulation of the task. Reiman's paper deals with transitivity but also connects to Toropainen's topic in that it touches upon the issue of the formulation of assignments. Seilonen has also employed the background data included in the Cefling Corpus, selecting texts written by healthcare workers and showing how their professional expertise is reflected in their test texts.

Tuija Määttä continues her research on the language skills of Swedish-speaking beginner-level learners of Finnish, based on the material of ICLFI (International Corpus of Learner Finnish). Her study provides points of comparison for other similar language-skill assessment projects. Ilmari Ivaska, in contrast, focuses on advanced learners of Finnish. His material represents learner Finnish from the LAS2 Corpus (University of Turku), especially one specific genre of academic writing: exam essays. Ivaska compares the use of a typical technique in academic writing, expressing modality with the verb voida 'can', in essays written by advanced Finnish learners and by native speakers.

The expressive verbs, which Marjatta Jomppanen investigated in $L V 21$ from the point of view of so-called colorative constructions (combinations of a neutral verb and an expressive one which describes or "colorizes" the action) in Sámi, are examined in this volume by MariaMagdalena Jürvetson, now for Finnish and from a different point of departure. Jürvetson's study is based on a question test assessing Finnish native speakers' knowledge of the meanings and semantic shades of expressive verbs. This method yields more detailed and up-to-date data than any dictionary can offer, and these data can also serve language teachers and learners in interpreting and using expressive verbs.

Leena Niiranen writes about an important and little known topic, the attempts to revitalise the Kven language in Norway in kindergartens by 
way of the so-called language nest (preschool immersion) method. Her analysis of the prerequisites for the successful application of this method is based on the activity theory model developed by Yrjö Engeström.

As already in the 22nd (together with Maria Heinonen) and 23rd issue of $L V$, Pirkko Muikku-Werner investigates receptive multilingualism: how native speakers of Finnish understand Estonian. Not only the similarity between sister languages but also the co-text plays a central role for the intelligibility of individual words and expressions.

Similarly to the previous issues of $L V$, this volume includes both studies and review articles. However, we have not divided the contents into subsections, as all articles have been peer-reviewed according to the usual principles of scholarly publication.

We would like to thank the authors for their diverse and insightful articles and the reviewers for their valuable comments which the authors have carefully taken into consideration. Our particular gratitude goes to our supporters: the Estonian Fund of the Alfred Kordelin Foundation, the Finno-Ugrian Cultural Foundation (Suomalais-ugrilaisen kulttuurirahaston säätiö), and the national programme "Estonian Language and Cultural Memory II" of the Estonian Ministry of Education and Research. It is of special importance for us that Lähivõrdlusi. Lähivertailuja can appear under the aegis of the Estonian Association for Applied Linguistics - our cordial thanks to the EAAL.

Tallinn, Vienna, Turku

Annekatrin Kaivapalu, Johanna Laakso, Kirsti Siitonen, and Katre Õim 